\title{
ВЗАИМОСВЯЗЬ ДИЭЛЕКТРИЧЕСКИХ СВОЙСТВ, МОРФОФИЗИОЛОГИЧЕСКИХ ХАРАКТЕРИСТИК, БИОХИМИЧЕСКОГО СОСТАВА И КАЧЕСТВА КОЖНО-ВОЛОСЯНОГО ПОКРОВА У ПУШНЫХ ЗВЕРЕЙ КЛЕТОЧНОГО СОДЕРЖАНИЯ*
}

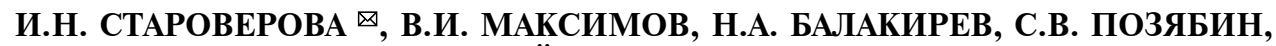 \\ С.Ю. ЗАЙЦЕВ, А.А. ДЕЛЬЦОВ
}

Волосяной покров пушных зверей, составляющий основу пушно-мехового сырья, относится к диэлектрическим материалам и способен электризоваться, то есть накапливать на поверхности заряды статического электричества. Это приводит к быстрому загрязнению пылыю, потери блеска волосяного покрова, ускоренному старению и разрушению волоса, снижению его прочностных характеристик и качества сырья, а также к передаче зарядов статического электричества при контакте, например с телом человека. В настоящей работе впервые выведено эмпирическое уравнение, описывающее диэлектрические свойства натурального меха, а также выявлены взаимосвязи состава и качества кожно-волосяного покрова с его электрофизическими характеристиками для разных видов пушных зверей клеточного содержания. Целью работы было изучение влияния морфофизиологических характеристик, биохимического состава (минерального и аминокислотного) и состояния кожно-волосяного покрова на его диэлектрические свойства и установление между этими показателями взаимосвязей, которые можно использовать для более точной и объективной оценки качества пушно-мехового сырья и полуфабриката. В работе использовали пушно-меховое сырье, полученное от физиологически здоровых животных - серебристо-черных лисиц (Vulpes vulpes), серебристых песцов (Alopex lagopus) и стандартных норок (Mustela vison) (ОАО зверосовхоз «Салтыковский», Московская обл.). Определяли характеристики кожно-

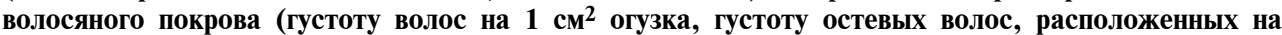

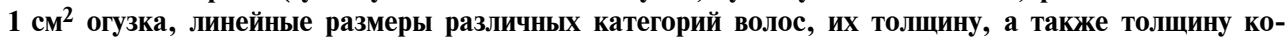
жевой ткани огузка и площадь шкурки) и минеральный состав по 18 элементам ( $\mathrm{Na}, \mathrm{Ni}, \mathrm{B}, \mathrm{V}$, $\mathrm{Se}, \mathrm{Al}, \mathrm{Fe}, \mathrm{K}, \mathrm{I}, \mathrm{Ca}, \mathrm{Co}, \mathrm{Mg}, \mathrm{Mn}, \mathrm{Cu}, \mathrm{P}, \mathrm{Cr}, \mathrm{Zn}, \mathrm{Si})$. Осуществляли аминокислотный анализ гидролизатов биосубстратов (по 17 аминокислотам). Шкурки, взятые после убоя животных, были использованы для исследования диэлектрических свойств. Уравнения кинетики разряда получены при $20{ }^{\circ} \mathrm{C}$, относительной влажности $62 \%$ и напряжении 10; 18,5 и 28,5 кВ на высоковольтном генераторе зарядов НT-705 5kVA 50KV AC/DC («Wuhan Huatian Electric Power Automation Co., Ltd.», Китай). При оценке качества пушно-мехового сырья использовали напряжение 9,5; 12,$5 ; 15,5$ и 18,5 кВ. Определяли постоянную времени утечки заряда, изменение величины напряженности статического электрического поля через определенные промежутки времени. Сопоставление морфофизиологических параметров кожного и волосяного покрова у представителей изученных видов с данными по электризуемости позволило вывести эмпирическое уравнение, отражающее диэлектрические свойства кожно-волосяных покровов пушных зверей, $-\mathbf{E}=\mathbf{E}_{0} \cdot \mathrm{e}^{-\mathbf{t} / \tau}$, где $\mathbf{E}_{0}$ - максимальное значение напряженности, $\tau$ - постоянная времени утечки заряда. Корреляционный анализ показал наличие тесных взаимосвязей между скоростью стекания заряда и длиной и толщиной остевых волос $(r=0,83-0,90$ при р $<0,05)$, густотой остевых и пуховых волос $(r=0,92-0,98$ при р $<0,001)$, а также длиной пуховых $(r=0,94$ при р $<0,001)$. Были установлены тесные корреляционные связи между утечкой заряда и суммарной массой элементов в волосяном и кожном покровах $(r=0,97 ; r=0,97$ при р $<0,05)$ и суммарным аминокислотным составом волосяного покрова $(r=0,95$ при $p<0,05)$, между значением Е0 и суммарной массой элементов в волосяном и кожном покровах, а также суммарным аминокислотным составом волосяного покрова $(r=-0,90 ; r=-0,86 ; r=-0,99$ при р $<0,05)$. Следовательно, диэлектрические свойства кожно-волосяного покрова пушных зверей зависят как от его морфофизиологических характеристик, так и от биохимического состава. Установлено, что на значение электрофизических показателей ( $\tau$ и Е0) влияет состояние кожно-волосяного покрова, его дефектность. Разреженность, стрижка, битость ости, свалянность волосяного покрова снижают показатель Е0 на 25$90 \%$ и изменяют постоянную времени утечки заряда $\tau$ на 15-70 \% по сравнению с бездефектными шкурками. Таким образом, для объективной и более точной оценки качества волосяного покрова серебристо-черной лисицы, серебристого песца и стандартной норки вместо органолептического анализа можно использовать диэлектрические показатели Ео и $\tau$, полученные с применением электрофизического оборудования.

* Работа выполнена в рамках гранта РФФИ «Разработка фармакологически активного соединения на основе полимерного комплекса для профилактики и лечения микроэлементозов в пушном звероводстве», № 20-016-00105/20. 
Ключевые слова: пушные звери, Vulpes vulpes, серебристо-черные лисицы, Alopex lagopus, серебристые песцы, Mustela vison, норки, кожно-волосяной покров, диэлектрические свойства, электризуемость, минеральный состав, аминокислотный состав, дефекты мехового сырья.

На меховых аукционах и предприятиях определение качества, целостности и состояния кожного и волосяного покрова пушных зверей, а также физико-механических характеристик, как правило, осуществляется устаревшими способами - вручную и органолептически $(1,2)$. Оценка качества мехового сырья и полуфабриката таким методом - трудоемкая, субъективная, часто спорная и неточная, поскольку зависит от опыта и профессионализма сортировщика, его самочувствия, утомляемости.

Кожно-волосяные покровы пушных зверей относятся к диэлектрическим материалам, которые способны накапливать значительный заряд статического электричества (2-4). Электризация пушно-мехового сырья и полуфабриката приводит к их быстрому загрязнению пылью, что ухудшает качество меховой продукции - снижает блеск, ускоряет старение и деструкцию волоса, повышает его ломкость (2).

Изучение электризуемости кожно-волосяного покрова и причин ее возникновения также необходимо для установления факторов, которые позволили бы снизить ее до безопасных для человека значений. К сожалению, на сегодняшний день в России и за рубежом подобные работы не проводятся. Нет ни методик, ни приборов, которые позволили бы исследовать процессы электризации, поскольку волосяной покров, в отличие от текстильных материалов, имеет неоднородную и неровную поверхность, состоящую из разных категорий волос с неодинаковым строением, линейными параметрами и геометрической формой. Для разработки как физической, так и математической модели электризуемости волосяного покрова нужно принимать во внимание все многочисленные нюансы, связанные с его сложной архитектоникой.

Волосяной покров пушных зверей, различающийся высотой, густотой, окраской волос, как и кожа животных, имеет неодинаковый минеральный и биохимический состав (5-7). Качество волосяного покрова зависит от полноценного кормления: сбалансированности белков, жиров, углеводов, витаминов, минеральных веществ (8-10) и других ингредиентов корма (11-13). Учесть влияние перечисленных выше факторов на электризацию меха (трибоэлектризацию, то есть поверхностную электризацию за счет трения) до сих пор не представлялось возможным.

В настоящей работе мы впервые выявили корреляции между биохимическим, минеральным составом, состоянием, морфофизиологическими характеристиками и диэлектрическими свойствами кожно-волосяного покрова у пушных зверей клеточного содержания. На основании этих данным установлено, что уменьшение напряженности электростатического поля на поверхности наэлектризованных шкурок со временем происходит по экспоненциальному закону и описывается формулой $\mathrm{E}=\mathrm{E} 0 \cdot \mathrm{e}^{-\mathrm{t} / \tau}$.

Целью работы было изучение влияния морфофизиологических характеристик, биохимического состава (минерального и аминокислотного) и состояния кожно-волосяного покрова на его диэлектрические свойства и установление взаимосвязей, которые можно использовать для более точной и объективной оценки качества пушно-мехового сырья и полуфабриката.

Методика. В работе использовали пушно-меховое сырье, полученное от физиологически здоровых животных: серебристо-черных лисиц (Vulpes vulpes), серебристых песцов (Alopex lagopus) и стандартных норок (Mustela vison) (ОАО зверосовхоз «Салтыковский», Московская обл.). Звери содержались в типовых шедах в условиях, принятых в хозяйстве для 
каждого вида, с соблюдением зоотехнических и ветеринарных требований. Рационы были общепринятыми, предусмотренными для соответствующего физиологического состояния, возраста животных, сезона года, тип кормления - мясо-рыбный в соответствии с рекомендациями ФГБНУ НИИПЗК им. В.А. Афанасьева, минеральный состав рационов анализировали согласно рекомендациям (14).

Характеристики кожно-волосяного покрова - густоту волос на $1 \mathrm{~cm}^{2}$ (усредненные значения общего числа волос, расположенных на $1 \mathrm{~cm}^{2}$ огузка, тыс.), густоту остевых волос, расположенных на 1 см$^{2}$ огузка, линейные размеры различных категорий волос, их толщину, а также толщину кожевой ткани огузка и площадь шкурки определяли согласно методическим рекомендациям (15). Проводили минерализацию образцов волос и кожи, разложение подготовленного биоматериала и определение минерального состава (общую концентрацию, мг\%) по 18 элементам ( $\mathrm{Na}, \mathrm{Ni}$, $\mathrm{B}, \mathrm{V}, \mathrm{Se}, \mathrm{Al}, \mathrm{Fe}, \mathrm{K}, \mathrm{I}, \mathrm{Ca}, \mathrm{Co}, \mathrm{Mg}, \mathrm{Mn}, \mathrm{Cu}, \mathrm{P}, \mathrm{Cr}, \mathrm{Zn}, \mathrm{Si})$ (15). Также определяли общую массу элементов, содержащихся в биосубстратах волосяного и кожного покровов на $1 \mathrm{~cm}^{2}$ огузка (мкг/ $\left.\mathrm{cm}^{2}\right)$.

Кислотный гидролиз биосубстратов волосяного покрова и кожи проводили по методике Н.А. Балакирева с соавт. (15). Гидролизаты анализировали по 17 аминокислотам: цистеину, треонину, серину, аспарагиновой и глутаминовой кислотам, глицину, пролину, аланину, метионину, изолейцину, лейцину, аргинину, валину, тирозину, фенилаланину, гистидину, лизину (15). Определяли общие концентрации аминокислот (мол.\%), присутствующих в гидролизатах биосубстратов.

Бездефектные шкурки стандартной норки (12 шт.), серебристого песца (12 шт.) и серебристо-черных лисиц (12 шт.), а также шкурки I и II сорта с разными видами дефектов (по 2 шт. с каждым), полученные после убоя животных в 7-месячном возрасте и подвергнутые стандартной первичной обработке, использовали для исследования диэлектрических свойств $(2,16)$. Уравнения кинетики разряда для волосяных покровов у разных видов пушных зверей получали при $20^{\circ} \mathrm{C}$, относительной влажности $62 \%$ и напряжении 10,$0 ; 18,5$ и 28,5 кВ на высоковольтном генераторе зарядов HT-705 5kVA 50KV AC/DC («Wuhan Huatian Electric Power Automation Co., Ltd.», Китай). При оценке качества пушно-мехового сырья использовали напряжение 9,5; 12,5; 15,5 и 18,5 кВ. На основании экспериментальных данных строили график зависимости изменения напряженности статического электрического поля (СЭП) от времени (кинетика разряда), по которому определяли постоянную времени утечки и скорость стекания заряда, а также максимальное значение напряженности СЭП (16). Измерение заряда и напряженности СЭП проводили до полного исчезновения заряда на образце. Повторные измерения выполняли пять раз.

Обработку результатов проводили согласно ГОСТ 8.207-76 (М., 1986). Статистический анализ осуществляли в программе Microsoft Excel. Определяли среднее арифметическое значения измеряемой величины $(M)$ и стандартную ошибку среднего $( \pm \mathrm{SEM})$. Для оценки достоверности различий между сравниваемыми средними значениями использовали $t$-критерий Стьюдента ( $\mathrm{p} \leq 0,05)$. Взаимосвязи между электрофизическими величинами, влияющими на электризуемость кожно-волосяного покрова, и его морфофизиологическими характеристиками и биохимическим составом устанавливали с помощью корреляционного анализа. Корреляционную связь считали слабой положительной или отрицательной при $r<0,3$ или $r>-0,3$, сильной положительной или отрицательной - при $r>0,69$ или $r<-0,69$, средней положительной или отрицательной - при $0,3<r<0,69$ 
и $-0,69<r<-0,3$. Для средней и сильной связи значения коэффициента корреляции были достоверны при р $<0,05$; $<<0,01 ; \mathrm{p}<0,001$.

Результаты. Известно, что диэлектрические свойства материалов зависят от их химического состава $(2,21)$. Поскольку электризуемость различных диэлектриков, в том числе натурального меха, относится к контактной электризации и представляет собой поверхностное явление, мы определяли как морфофизиологические параметры кожно-волосяного покрова (табл. 1), так и поверхностную концентрацию макро- и микроэлементов (табл. 2), то есть суммарные массы элементов в биосубстратах волосяного и кожного покровов в расчете на $1 \mathrm{~cm}^{2}$ огузка, а также аминокислотный состав биосубстратов (см. табл. 2).

1. Морфофизиологическая характеристика кожно-волосяного покрова у серебристо-черных лисиц (Vulpes vulpes), серебристых песцов (Alopex lagopus) и стандартных норок (Mustela vison) $(n=12$, M $(\mathrm{SEM}$; ОАО зверосовхоз «Салтыковский», Московская обл., 2014 год)

\begin{tabular}{l|c|c|c}
\hline \multicolumn{1}{c|}{ Показатель } & $\begin{array}{l}\text { Серебристо-черная } \\
\text { лисица }\end{array}$ & Серебристый песец & Стандартная норка \\
\hline Густота волос, тыс/см ${ }^{2}$ & $20,5 \pm 0,5$ & $35 \pm 1$ & $9,5 \pm 0,3$ \\
Густота остевых волос, шт/см² & $420 \pm 20$ & $540 \pm 30$ & $240 \pm 20$ \\
Длина остевых волос, мм & $69,1 \pm 0,3$ & $66,7 \pm 0,3$ & $29,7 \pm 0,2$ \\
Длина пуховых волос, мм & $42,7 \pm 0,2$ & $43,5 \pm 0,1$ & $13,7 \pm 0,2$ \\
Толщина остевых волос, мкм & $45,9 \pm 0,4$ & $47,6 \pm 0,3$ & $60,1 \pm 0,4$ \\
Толщина пуховых волос, мкм & $10,5 \pm 0,3$ & $10,6 \pm 0,1$ & $9,3 \pm 0,2$ \\
Толщина кожевой ткани, мм & $0,63 \pm 0,04$ & $0,72 \pm 0,01$ & $0,82 \pm 0,01$ \\
\hline
\end{tabular}

2. Минеральный и аминокислотный состав кожного и волосяного покровов у серебристо-черных лисиц (Vulpes vulpes), серебристых песцов (Alopex lagopus)

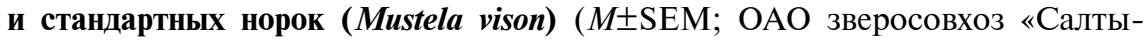
ковский», Московская обл., 2014 год)

\begin{tabular}{|c|c|c|c|}
\hline Показатель & $\begin{array}{l}\text { Серебристо- } \\
\text { черная лисица }\end{array}$ & $\begin{array}{l}\text { Серебристый } \\
\text { песец }\end{array}$ & $\begin{array}{l}\text { Стандартная } \\
\text { норка }\end{array}$ \\
\hline \multicolumn{4}{|c|}{ М ине р альны й состав $(n=20)$} \\
\hline Общая концентрация макро- и & & & \\
\hline микроэлементов в волосяном покрове, мг\% & $107,8 \pm 1,9$ & $99,1 \pm 1,7$ & $59,1 \pm 1,5$ \\
\hline Общая концентрация макро- и & & & \\
\hline микроэлементов в кожном покрове, мг\% & $148,0 \pm 2,0$ & $183,0 \pm 3,0$ & $116,3 \pm 1,9$ \\
\hline 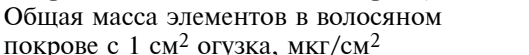 & $10609+070$ & $16141+015$ & $2502+0$ \\
\hline Общая масса элементов в кожном покрове & $100,0 Y \perp 0, / 0$ & $101,41 \pm 0,15$ & $25,0 \angle \pm 0,14$ \\
\hline на $1 \mathrm{~cm}^{2}$ огузка, мкг $/ \mathrm{cm}^{2}$ & $75,83 \pm 0,05$ & $108,78 \pm 0,11$ & $77,16 \pm 0,03$ \\
\hline \multicolumn{4}{|c|}{ Аминокислотный состав $(n=12)$} \\
\hline Аминокислотный состав волос, мол.\% & $90,76 \pm 0,18$ & $94,50 \pm 0,20$ & $86,67 \pm 0,19$ \\
\hline Аминокислотный состав кожи, мол.\% & $88,40 \pm 0,10$ & $89,50 \pm 0,10$ & $89,30 \pm 0,10$ \\
\hline
\end{tabular}

У наэлектризованных образцов пушно-мехового сырья наблюдалось стекание заряда с поверхности в окружающее пространство, то есть величина заряда со временем уменьшалась. Это приводило к ослаблению СЭП и, как следствие, к уменьшению напряженности этого поля (Е) по сравнению с первоначальным значением (Е0).

Для удобства сравнения различных по составу и диэлектрическим свойствам материалов используют величину удельного объемного сопротивления (R) при одинаковых атмосферных условиях (относительной влажности и температуре). Волокнистые природные протеиновые материалы (шерсть, натуральный мех, шелк) имеют $\mathrm{R}=10^{9}-10^{13} \mathrm{Oм} \cdot \mathrm{м}$, тогда как у синтетических волокон, применяемых для производства искусственного меха, $\mathrm{R}=10^{10}-10^{18}$ Ом $\cdot$ м (2). Поэтому изделия из искусственного меха накапливают на поверхности больший заряд, то есть сильнее электризуются, чем натуральный мех, и требуют дополнительной антистатической обработки. Кроме того, на безопасную утилизацию искусственного меха, ко- 
торый не подвержен естественному разложению, необходимы дополнительные затраты. Также важно отметить, что материалы из натуральных волокон (в отличие от синтетических) в процессе трибоэлектризации способствуют накоплению на коже человека отрицательных зарядов, благотворно влияющих на здоровье (2). Следовательно, натуральный мех эстетически, гигиенически и экологически предпочтительнее искусственного.

3. Аналитический вид уравнений кинетики разряда $\mathrm{y}=\operatorname{lgE}$ при разном напряжении на генераторе зарядов (U) для волосяных покровов серебристо-черных лисиц (Vulpes vulpes), серебристых песцов (Alopex lagopus) и стандартных норок (Mustela vison) ( $n=12, M \pm \mathrm{SEM}$; ОАО зверосовхоз «Салтыковский», Московская обл., 2014 год)

\begin{tabular}{l|c|c|c}
\hline Вид животного & $\mathrm{U}, \mathrm{kB}$ & $\mathrm{y}=-\mathrm{at}+\mathrm{b}$, где b $=\lg \mathrm{E}_{0}$ & $\mathrm{E}_{0}, \mathrm{kB} / \mathrm{M}$ \\
\hline Серебристо-черная лисица & 10,0 & $\mathrm{y}=-0,0064 \mathrm{t}+5,34$ & $219 \pm 11$ \\
& 18,5 & $\mathrm{y}=-0,0049 \mathrm{t}+5,58$ & $380 \pm 20$ \\
Серебристый песец & 28,5 & $\mathrm{y}=-0,0014 \mathrm{t}+5,77$ & $590 \pm 30$ \\
& 10,0 & $\mathrm{y}=-0,0031 \mathrm{t}+5,14$ & $138 \pm 11$ \\
Стандартная норка & 18,5 & $\mathrm{y}=-0,0026 \mathrm{t}+5,37$ & $370 \pm 20$ \\
& 28,5 & $\mathrm{y}=-0,0008 \mathrm{t}+5,57$ & $234 \pm 15$ \\
& 10,0 & $\mathrm{y}=-0,0081 \mathrm{t}+5,37$ & $372 \pm 19$ \\
\hline
\end{tabular}

П р и м е ч н и е. Е0 - максимальная величина напряженности статического электрического поля, Е величина напряженности статического электрического поля в момент времени t. 3начения R ${ }^{2}$, характеризующие достоверность аппроксимации, составили 0,83-0,98. Повторные измерения выполняли пять раз.

Мы сопоставили полученные результаты с известными из литературы данными о влиянии природы материалов (политетрафторэтилена, полиуретана, нержавеющей стали и латекса, контактирующих между собой) (17), их структуры (волокнистой или гранулированной) $(18,19)$ и формы поверхности $(20,21)$ на диэлектрические свойства. Это позволило вывести уравнение кинетики разряда, описывающее изменение напряженности СЭП кожно-волосяных покровов пушных зверей со временем. Оказалось, что изменение происходит по экспоненциальному закону: $\mathrm{E}=\mathrm{E}_{0} \cdot \mathrm{e}^{-\mathrm{t} / \tau}$. После логарифмирования уравнение приобретает вид $\lg \mathrm{E}=\lg \mathrm{E}_{0}-\mathrm{t} / \tau \cdot \operatorname{lge}$, или $\lg \left(\mathrm{E} / \mathrm{E}_{0}\right)=-0,434 \mathrm{t} / \tau$, где $\mathrm{E}-$ величины напряженности СЭП в момент времени $\mathrm{t}$; Е 0 - величины напряженности СЭП в момент времени $\mathrm{t}=0$ (параметр $b$, табл. 3), $\tau$ - постоянная времени стекания заряда, или времени удерживания заряда, определяемая как время уменьшения величины напряженности электрического поля в 2 раза. Скорость стекания заряда определялась по величине тангенса угла наклона линейной зависимости (параметр а, см. табл. 3), соответствующей изменению $\lg$ о от времени, к оси времени. При этом для всех видов пушно-мехового сырья наблюдалась общая тенденция: с ростом степени электризации волосяного покрова (Е0) снижалась скорость утечки заряда (см. табл. 3). Следует отметить, что в приведенных выше работах обсуждаются разные математические модели по электризации (трибоэлектризации) материалов в зависимости от состава, природы и формы контактирующих материалов (17-21), приводятся методики, позволяющие получать воспроизводимые данные $(20,21)$. Однако во всех этих работах рассматриваются более простые по структуре и составу объекты в сравнении с волосяным покровом пушных зверей.

Поскольку у разных видов пушных зверей кожно-волосяной покров заметно различается по совокупности морфофизиологических и биохимических характеристик, мы провели корреляционный анализ для выявления основных параметров, в наибольшей степени сказывающихся на диэлектрических свойствах мехового сырья. Сильная корреляционная связь 
наблюдалась между скоростью стекания заряда и длиной и толщиной остевых волос $(r=0,83-0,90$ при р $<0,05)$, длиной пуховых волос $(r=0,94$ при $\mathrm{p}<0,001)$, густотой остевых и пуховых волос $(r=0,92-0,98$ при $\mathrm{p}<0,001)$. Были выявлены сильные положительные и отрицательные корреляционные связи между скоростью стекания заряда и общей массой элементов в кожном и волосяном покровах, общим аминокислотным составом волосяного покрова $(r=0,97 ; r=0,97 ; r=0,95$ при р $<0,05)$, а также между величиной Е0 и вышеупомянутыми показателями для кожного и волосяного покрова $(r=-0,90 ; r=-0,86 ; r=-0,99$ при р $<0,05)$. Средние и слабые корреляционные связи отмечали между минеральным составом волосяного покрова (общей концентрацией макро-, микроэлементов в волосяном покрове), общим аминокислотным составом кожного покрова и скоростью стекания заряда $(r=0,64 ; r=0,29$ при р $<0,05)$ и величиной Е $0(r=-0,43$; $r=-0,54$ при р $<0,05)$. Следовательно, диэлектрические свойства кожноволосяного покрова, его морфофизиологические характеристики, а также биохимический состав взаимосвязаны друг с другом.

Бездефектные шкурки пушных зверей можно получить только при сбалансированном и правильно организованном кормлении и содержании животных. В противном случае недостаток питательных (белки, жиры, углеводы) (22), минеральных веществ (23-25) и витаминов (26) в кормах приводит к развитию заболеваний (минерального, иммунного дефицитов, различных авитаминозов), связанных с появлением прижизненных пороков волосяного покрова $(22,27)$. Обычно прижизненные пороки, снижающие качество и ценность пушно-мехового сырья, возникают вследствие нарушенной линьки, механических повреждений, избыточного загрязнения волосяного покрова, кожных заболеваний, а также из-за неполноценного питания и неправильного содержания пушных зверей.

Так, разреженность волосяного покрова, при которой на шкурках есть участки с уменьшенной густотой волос по сравнению с нормальной, вызвана недостатком витаминов группы В, В9, фолиевой кислоты $(22,28$, $29)$, витамина С $(22,30,31)$. В результате чесотки, стригущего лишая, а также механических повреждений из-за неудобных для зверей лазов в шедах на кожно-волосяном покрове появляются участки, лишенные волосяного покрова (проплешины) (22). Во многих хозяйствах с частотой до $30 \%$ у зверей отмечают скусывание волос с шеи, спины, хвоста. Это поведение (так называемая стрижка) наблюдается обычно у норок и песцов, реже у лисиц. Причиной считаются нарушения в технологии приготовления кормов, в которых присутствуют окислившиеся субпродукты, а также недокорм животных, использование кормосмесей с дисбалансом аминокислот, дефицитом биотина и скармливание пушным зверям большого количества костей $(15,22)$. Недостаток в рационах пушных зверей серосодержащих аминокислот, витаминов группы В, а также серы, магния, меди и кобальта приводит к возникновению таких прижизненных пороков, как битость ости или сеченность (облом верхней части стержня кроющих волос волосяного покрова). Ранее мы показали, что минеральный состав волосяного покрова у больных песцов сильно отличается по вышеупомянутым элементам от такового у здоровых животных (32), и, возможно, именно эти элементы влияют на процессы кератинизации волос. Из-за недостаточной кератинизации волосяного стержня волос теряет эластичность, что сопровождается самопроизвольной ломкостью, снижающей качество опушения и ценность пушно-мехового сырья (22). Битость ости, как правило, впоследствии приводит к свалянности, то есть появлению участков со спу- 
танным войлокообразным волосяным покровом и нарушенным соотношением волос определенных категорий. Это заболевание вызывают плохие условия содержания и некачественное кормление пушных зверей (22).

Перечисленные прижизненные пороки пушно-мехового сырья составляют лишь небольшую часть дефектов, связанных как с плохим кормлением и содержанием животных, так и с погрешностями при хранении и технологических обработках шкурок после забоя и при получении мехового сырья. На наш взгляд, объективную оценку качества пушно-мехового сырья (особенно больших объемов) по всей совокупности характеристик удобно проводить с помощью электрофизического оборудования.

Диэлектрические свойства пушно-мехового сырья (шкурки серебристо-черной лисицы, серебристого песца и стандартной норки) оказались очень чувствительными к целостности кожно-волосяного покрова и наличию на нем различных дефектов. Мы подвергали воздействию статического электричества образцы с различными видами дефектов (разреженность, свалянность, стрижка, проплешины, битость ости) и без дефектов. Полученные результаты показали, что наличие этих дефектов влияет на электризуемость мехового сырья (табл. 4). При этом изменялся как аналитический вид уравнений кинетики разряда $(\mathrm{y}=-\mathrm{at}+\mathrm{b}$, где $\mathrm{y}=\lg \mathrm{E}$, $\left.\mathrm{b}=\lg \mathrm{E}_{0}\right)$, так и электрофизические величины, характеризующие диэлектрические свойства (максимальное значение напряженности Е0 и постоянная времени утечки заряда $\tau)$.

4. Влияние дефектов кожно-волосяного покрова на его электрофизические показатели у серебристо-черных лисиц (Vulpes vulpes), серебристых песцов (Alo-

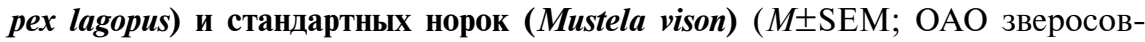
хоз «Салтыковский», Московская обл., 2014 год)

\begin{tabular}{|c|c|c|c|c|c|}
\hline Вид животного & $\mathrm{U}, \mathrm{\kappa B}$ & $\begin{array}{l}\text { Сорт, группа } \\
\text { дефектности }\end{array}$ & $\begin{array}{c}\mathrm{y}=-\mathrm{at}+\mathrm{b} \\
\text { где } \mathrm{y}=\lg \mathrm{E}, \mathrm{b}=\lg \mathrm{E}_{0}\end{array}$ & $\mathrm{E}_{0}, \mathrm{~KB} / \mathrm{M}$ & $\tau, \mathrm{c}$ \\
\hline \multirow{8}{*}{ Серебристо-черная лисица } & 9,5 & I сорт, без дефекта & $\mathrm{y}=-0,0015 \mathrm{t}+5,00$ & $97 \pm 7$ & $289 \pm 7$ \\
\hline & 12,5 & I сорт, без дефекта & $y=-0,0019 t+5,13$ & $140 \pm 10$ & $219 \pm 10$ \\
\hline & 15,5 & I сорт, без дефекта & $\mathrm{y}=-0,0024 \mathrm{t}+5,21$ & $160 \pm 10$ & $180 \pm 10$ \\
\hline & 18,5 & I сорт, без дефекта & $\mathrm{y}=-0,0031 \mathrm{t}+5,28$ & $190 \pm 10$ & $140 \pm 7$ \\
\hline & 9,5 & I сорт, 1-я группа & $y=-0,0013 t+4,47$ r & $31 \pm 7$ & $340 \pm 20$ \\
\hline & 12,5 & II сорт, 2-я группа & $y=-0,0009 t+4,57^{\text {в }}$ & $35 \pm 9$ & $340 \pm 20$ \\
\hline & 15,5 & I сорт, 1-я группа & $\mathrm{y}=-0,0020 \mathrm{t}+4,44^{\mathrm{a}}$ & $31 \pm 8$ & $220 \pm 30$ \\
\hline & 18,5 & I сорт, 2-я группа & $y=-0,0023 t+5,08^{\text {д }}$ & $120 \pm 10$ & $190 \pm 20$ \\
\hline \multirow[t]{8}{*}{ Серебристый песец } & 9,5 & I сорт, без дефекта & $y=-0,0029 t+5,23$ & $180 \pm 20$ & $144 \pm 8$ \\
\hline & 12,5 & I сорт, без дефекта & $y=-0,0024 t+5,27$ & $197 \pm 19$ & $185 \pm 9$ \\
\hline & 15,5 & I сорт, без дефекта & $y=-0,0019 t+5,31$ & $201 \pm 19$ & $210 \pm 10$ \\
\hline & 18,5 & I сорт, без дефекта & $y=-0,0014 t+5,34$ & $230 \pm 20$ & $324 \pm 17$ \\
\hline & 9,5 & I сорт, 1-я группа & $\mathrm{y}=-0,0024 \mathrm{t}+4,41^{\mathrm{r}}$ & $32 \pm 9$ & $181 \pm 17$ \\
\hline & 12,5 & II сорт, 2-я группа & $\mathrm{y}=-0,0012 \mathrm{t}+4,64^{\mathrm{B}}$ & $38 \pm 9$ & $360 \pm 20$ \\
\hline & 15,5 & I сорт, 1-я группа & $\mathrm{y}=-0,0017 \mathrm{t}+4,86^{\mathrm{a}}$ & $77 \pm 9$ & $255 \pm 15$ \\
\hline & 18,5 & I сорт, 2-я группа & $\mathrm{y}=-0,0012 \mathrm{t}+5,11$ д & $130 \pm 15$ & $378 \pm 19$ \\
\hline \multirow[t]{8}{*}{ Стандартная норка } & 9,5 & I сорт, без дефекта & $y=-0,0037 t+5,22$ & $164 \pm 8$ & $126 \pm 6$ \\
\hline & 12,5 & I сорт, без дефекта & $\mathrm{y}=-0,0028 \mathrm{t}+5,30$ & $200 \pm 9$ & $159 \pm 8$ \\
\hline & 15,5 & I сорт, без дефекта & $y=-0,0026 t+5,28$ & $178 \pm 10$ & $171 \pm 8$ \\
\hline & 18,5 & I сорт, без дефекта & $\mathrm{y}=-0,0017 t+5,45$ & $290 \pm 10$ & $271 \pm 11$ \\
\hline & 9,5 & I сорт, 1-я группа & $\mathrm{y}=-0,0018 \mathrm{t}+4,18^{\mathrm{a}}$ & $18 \pm 3$ & $250 \pm 50$ \\
\hline & 12,5 & II сорт, 1-я группа & $y=-0,0008 t+5,40^{6}$ & $263 \pm 15$ & $531 \pm 19$ \\
\hline & 15,5 & II сорт, 2-я группа & $\mathrm{y}=-0,0017 \mathrm{t}+4,72^{\mathrm{B}}$ & $57 \pm 11$ & $275 \pm 18$ \\
\hline & 18,5 & I сорт, 1-я группа & $\mathrm{y}=-0,0013 \mathrm{t}+5,12^{\mathrm{r}}$ & $143 \pm 15$ & $319 \pm 16$ \\
\hline \multicolumn{6}{|c|}{$\begin{array}{l}\text { П р и м е ч а н и е. Для шкурок без дефекта } n=12 \text {, для шкурок с каждым видом дефекта } n=2 \text {; а }- \text { раз- } \\
\text { реженность волосяного покрова, } 6-\text { проплешина, в - стрижка, г - битость ости, д - свалянность воло- } \\
\text { са. U - напряжение на генераторе зарядов. Е0 - максимальная величина напряженности статического } \\
\text { электрического поля, Е - величина напряженности статического электрического поля в момент времени } \\
\mathrm{t}, \tau-\text { постоянная времени утечки заряда. Значения } \mathrm{R}^{2} \text {, характеризующие достоверность аппроксимации, } \\
\text { составили } 0,77-0,99 \text {. Повторные измерения выполняли пять раз. }\end{array}$} \\
\hline
\end{tabular}

Для всех видов пушно-мехового сырья разреженность волосяного покрова снижала значения Е0 на 60-90 \% и $\tau$ на 20-50 \% по сравнению с 
бездефектными шкурками, битость ости - соответственно на 50-80 и 15$20 \%$, стрижка - на 70-80 и 40-50 \%, проплешины - на 25 и 70 \% для норок, свалянность волосяного покрова - на 40 и 15-25 \% для песцов и лисиц (см. табл. 4).

Таким образом, морфофизиологические и биохимические характеристики кожно-волосяного покрова пушных зверей оказывают сильное влияние на диэлектрические свойства мехового сырья. Корреляционный анализ показал тесную зависимость утечки заряда и максимальной напряженности статического электрического поля (Е0) кожно-волосяного покрова от густоты, длины, толщины остевых и пуховых волос, а также от их минерального и аминокислотного состава. Диэлектрические свойства также зависят от качества меховой продукции, наличия дефектов. Прижизненные пороки (разреженность, стрижка, битость ости, свалянность волосяного покрова) снижают показатель Е0 на 25-90 \% и изменяют постоянную времени утечки заряда $\tau$ на $15-70 \%$ по сравнению с бездефектными шкурками, в то время как проплешины, наоборот, увеличивают время стекания заряда и максимальную величину напряженности Е0. На основании представленных результатов мы можем рекомендовать диэлектрические показатели Е0 и $\tau$ для контроля качества пушно-мехового сырья, полученного от серебристо-черной лисицы, серебристого песца и стандартной норки. Этот подход основан на применении электрофизического оборудования и (в отличие от субъективного органолептического определения) позволяет объективно и более точно оценить товарные свойства звероводческой пушнины.

ФГБОУ ВО Московская государственная академия Поступила в редакцию ветеринарной медицины и биотехнологии 12 апреля 2021 года

МВА им. К.И. Скрябина,

109472 Россия, г. Москва, ул. Академика Скрябина, 23,

e-mail: irina_starovierova@mail.ru $\bigotimes$,dr.maximov@gmail.com,

Balakirev@mgavm, rector@mgavm, szaitsev@mail.ru, deltsov-81@mail.ru

Sel'skokhozyaistvennaya biologiya [Agricultural Biology], 2021, V. 56, № 4, pp. 809-818

\title{
RELATIONSHIP OF DIELECTRIC PROPERTIES OF THE HAIR COVER WITH ITS MORPHOPHYSIOLOGICAL AND BIOCHEMICAL CHARACTERISTICS IN FARMED FUR-BEARING ANIMALS
}

\author{
I.N. Staroverova ${ }^{凶}$, V.I. Maksimov, N.A. Balakirev, S.V. Pozyabin, S.Yu. Zaitsev, \\ A.A. Deltsov
}

Skryabin Moscow State Academy of Veterinary Medicine and Biotechnology, 23, ul. Akademika K.I. Skryabina, Moscow, 109472 Russia, e-mail irina_starovierova@mail.ru ( $\square$ corresponding author), dr.maximov@gmail.com, Balakirev@mgavm, rector@mgavm, szaitsev@mail.ru, deltsov-81@mail.ru

ORCID:

Staroverova I.N. orcid.org/0000-0003-3762-9956

Maksimov V.I. orcid.org/0000-0002-5305-0218

Balakirev N.A. orcid.org/0000-0001-8980-263X

Pozyabin S.V. orcid.org/0000-0002-3825-6082

Zaitsev S.Yu. orcid.org/0000-0003-1533-8680

Deltsov A.A. orcid.org/000-002-0385-0321

Acknowledgements:

Supported financially by the Russian Foundation for Basic Research within the frame of grant No. 20-016-00105/20

"Development of a pharmacologically active compound based on a polymer complex for the prevention and treatment of microelementosis in fur farming"

Received April 12, 2021

doi: 10.15389/agrobiology.2021.4.809eng

\section{Abstract}

The hair cover of furbearing animals is a dielectric material able to electrify with accumulation of static electricity charges. Electrically charged surface attracts dust particles causing loss of fur shine, accelerated aging, destruction and a decrease in strength characteristics and the quality of raw materials, as well as the transfer of static electricity charges when in contact, for example, with the human body. In this paper, for the first time, we propose an empirical equation describing the die- 
lectric properties of natural fur and the interrelations between the composition and quality of the skin and hair covers with its electrophysical characteristics for different species of furbearing farm animals. The work aimed to study the influence of morphophysiological characteristics, biochemical composition (mineral and amino acid), and the state of the skin and hair on dielectric properties and to reveal relationships to more correctly assess the quality of fur raw materials. In the work, we used fur raw materials obtained from physiologically healthy silver-black foxes (Vulpes vulpes), silver foxes (Alopex lagopus), and standard minks (Mustela vison) (Zverosovkhoz Saltykovsky, Moscow Province). Hair density per $1 \mathrm{~cm}^{2}$ rump, the guard hair density per $1 \mathrm{~cm}^{2}$ rump, the linear dimensions of various types of hair, their thickness, the thickness of the rump skin, and the pelt area were measured and $\mathrm{Na}, \mathrm{Ni}, \mathrm{B}, \mathrm{V}, \mathrm{Se}, \mathrm{Al}, \mathrm{Fe}, \mathrm{K}, \mathrm{I}, \mathrm{Ca}, \mathrm{Co}, \mathrm{Mg}, \mathrm{Mn}, \mathrm{Cu}, \mathrm{P}, \mathrm{Cr}, \mathrm{Zn}$, Si contents were determined. Amino acid analysis of biosubstrate hydrolysates was carried out for 17 amino acids. The pelts were tested for dielectric properties. The discharge kinetics equations were obtained at $20^{\circ} \mathrm{C}, 62 \%$ relative humidity and voltage of 10.0, 18.5, and $28.5 \mathrm{kV}$ (a HT-705 5kVA 50KV AC/DC high-voltage charge generator, Wuhan Huatian Electric Power Automation Co., Ltd., China). When assessing the quality of fur raw materials, a voltage of $9.5,12.5,15.5$ and $18.5 \mathrm{kV}$ was used. The charge leakage time constant and the change in the magnitude of the static electric field intensity at certain time intervals were determined. A comparison of the morphophysiological parameters of the skin and hair in different species of furbearing animals with the data on electrizability allowed us to derive an empirical equation reflecting the dielectric properties of the skin and hair $-E=E_{0} \cdot e^{-t / \tau}$, where $E_{0}$ is the maximum value of the tension and $\tau$ is the charge leakage time constant. Correlation analysis showed close interrelations between the rate of charge runoff and the length and thickness of the guard hairs $(r=0.83-0.90$ at $\mathrm{p}<0.05)$, the density of the guard and down hair $(r=0.92-0.98$ at $\mathrm{p}<0.001)$, and the length of the down hairs $(r=0.94$ at $\mathrm{p}<0.001)$. The charge leakage closely correlated with the total mass of chemical elements in the hair and skin $(r=0.97 ; r=0.97$ at $\mathrm{p}<0.05)$ and the total amino acid composition of the hair cover $(r=0.95$ at $\mathrm{p}<0.05)$. The E0 value closely correlated with the total mass of elements in the hair and skin, and with the amino acid composition of the hair cover $(r=0.90$; $r=0.86 ; r=0.99$ at $\mathrm{p}<0.05$ ). Therefore, the dielectric properties of the skin and hair of furbearing animals depend on both the morphophysiological characteristics and biochemical composition. The skin and hair cover defects were established to affect the electrophysical parameters ( $\tau$ and E0). Decreased fur density, haircut, broken awn, fur mattedness reduce the $\mathrm{E}_{0}$ index by $25-90 \%$ and change the charge leakage time constant $\tau$ by $15-70 \%$ compared to defect-free skins. The dielectric parameters $\mathrm{E}_{0}$ and $\tau$ provide more accurate fur quality estimates in silver-black fox, silver fox, and standard mink. The technology uses electrophysical measurements instead of not subjective organoleptic analysis.

Keywords: furbearing animals, Vulpes vulpes, silver fox, Alopex lagopus, Arctic fox, Mustela visonm, mink, skin cover, hair cover, dielectric properties, electrizability, mineral composition, amino acid composition, fur defects.

\section{REFEREN C ES}

1. Golovteeva A.A., Kutsidi D.A., Sankin L.B. Laboratornyi praktikum po khimii $i$ tekhnologii kozhi $i$ mekha [Laboratory workshop on leather and fur chemistry and technology]. Moscow, 1987 (in Russ.).

2. Staroverova I.N., Kuleshov I.V., Os'kina O.Yu., Zaitsev S.Yu., Maksimov V.I. Vozniknovenie staticheskogo elektrichestva na razlichnykh materialakh $i$ metody ego otsenki [The emergence of static electricity on various materials and methods for its assessment]. Moscow, 2008 (in Russ.).

3. Bychkova I.N. Razrabotka otdelochnykh kompozitsii na baze fibrillyarnykh belkov dlya ispol'zovaniya $v$ proizvodstve mekha. Avtoreferat kandidatskoi dissertatsii [Development of finishing compositions based on fibrillar proteins for use in fur production. PhD Thesis]. Moscow, 2005 (in Russ.).

4. Kislyakov A.G., Mordvinkin I.N. Biofizika, 2001, 46(1): 93-97 (in Russ.).

5. Canids: foxes, wolves, jackals and dogs. Status survey and conservation action plan. C. SilleroZubiri, M. Hoffmann, D.W. Macdonald (eds.). IUCN/SSC Canid Specialist Group, Gland, Switzerland and Cambridge, UK, 2004.

6. Balakirev N.A., Zaitsev S.Yu., Rizvanov A.A. Phenozan influence on the physiologicalbiochemical parameters of the young minks leading to their advanced properties. International Journal of Zoology, 2016, 2016: 2159509 (doi: 10.1155/2016/2159509).

7. Damgaard B.M., Børsting C.F., Engberg R.M., Jensen S.K. Effects of high dietary levels of fresh or oxidised fish oil on performance and blood parameters in female mink (Mustela vison) during the winter, reproduction, lactation and early growth periods. Acta Agriculturae Scandinavica, Section A - Animal Science, 2003, 53(3): 136-146 (doi: 10.1080/09064700310011198).

8. Zhong W., Mu L.L., Han F.F., Luo G.L., Zhang X.Y., Liu K.Y., Guo X.L., Yang H.M., Li G.Y. Estimation of the net energy and protein requirements for maintenance of male Arctic foxes (Alopex lagopus) during the growth period1,2. J. Anim. Sci., 2019, 97(11): 4579-4587 (doi: $10.1093 / \mathrm{jas} / \mathrm{skz} 253)$. 
9. Cybulski W., Jarosz L., Chałabis-Mazurek A., Jakubczak A., Kostro K., Kursa K. Contents of zinc, copper, chromium and manganese in silver foxes according to their age and mineral supplementation. Pol. J. Vet. Sci., 2009, 12(3): 339-245.

10. Zhong W., Liu H. Luo G., Chang Z. Liu F., Zhao J., Li D., Yue Z., Zhang H., Li G. Dietary copper supplementation improves pelt characteristics of female silver fox (Vulpes fulva) during the winter fur-growing season. Anim. Sci. J., 2014, 85(7): 757-762 (doi: 10.1111/asj.12208).

11. Fouda T.A., Youssef M.A., El-Deeb W.M. Correlation between zinc deficiency and immune status of sheep. Veterinary Research, 2011, 4(2): 50-55 (doi: 10.3923/vr.2011.50.55).

12. Staroverova I.N., Maksimov V.I., Zaitsev S.Yu. Doklady Rossiiskoi akademii sel'skokhozyaistvennykh nauk, 2010, 5: 42-44 (in Russ.).

13. Dayyani N., Beyki Bandar Abadi M., Amir Abadi Farhani A. Chelated minerals in animal nutrition. International Journal of Advanced Biological and Biomedical Research, 2013, 1(11): 13871391.

14. Balakirev N.A., Kladovshchikov V.F. Normy zatrat kormov dlya pushnykh zverei $i$ krolikov: Spravochnoe posobie [Feed cost rates for fur animals and rabbits: A reference guide]. Moscow, 2007 (in Russ.).

15. Balakirev N.A., Maksimov V.I., Staroverova I.N., Zaitsev S.Yu., Balakirev A.N. Biologicheskaya rol' mineral'nykh veshchestv v kletochnom pushnom zverovodstve (norkovodstve) [The biological role of minerals under cage-based fur factoru farming (mink breeding)]. Moscow, 2017 (in Russ.).

16. Egorov V.N. Plasticheskie massy, 1965, 1: 62-64 (in Russ.).

17. Sow M., Lacks D.J., Sankaran R.M. Effects of material strain on triboelectric charging: influence of material properties. Journal of Electrostatics, 2013, 71(3): 396-399 (doi: 10.1016/j.elstat.2012.11.021).

18. Tabti B., Dascalescu L., Plopeanu C.M., Antoniu M.A., Mekideche R. Factors that influence the corona charging of fibrous dielectric materials. Journal of Electrostatics, 2009, 69(2-3): 193197 (doi: 10.1016/j.elstat.2009.01.047).

19. Forward K.M., Lacks D.J., Sankaran R.M. Methodology for studying particle-particle triboelectrification in granular materials. Journal of Electrostatics, 2009, 67(2-3): 178-183 (doi: 10.1016/j.elstat.2008.12.002).

20. Coste J., Pechery R. Influence of surface profile in polymer-metal contact charging. Journal of Electrostatics, 1981, 10: 129-136 (doi: 10.1016/0304-3886(81)90032-2).

21. Girardi M. Charge dynamics in a model for grains electrization. Journal of Electrostatics, 2010, 68(5): 409-414 (doi: 10.1016/j.elstat.2010.05.012).

22. Balakirev N.A., Perel'dik D.N., Domskii I.A. Soderzhanie, kormlenie i bolezni kletochnykh push$n y k h$ zverei [Maintenance, feeding, and diseases of fur animals under caged farming]. Moscow, 2013 (in Russ.).

23. Rogowska K.A., Mondiewich J., Grosichi A. Lead, cadmium, arsenic, copper, and zinc contents it in hair of cattle living in the area contaminated by a copper smelter in 2006-2008. Bulletin of the Veterinary Institute in Puławy, 2009, 53(4): 703-706.

24. Fouda T.A., Youssef M.A., El-Deeb W.M. Serum copper concentration and immune status of sheep: clinical and laboratory study. Veterinary Research, 2012, 5: 16-21.

25. Pal D.T., Gowda N.K., Prasad C.S., Amarnath R., Bharadwaj U., Suresh Babu G., Sampath K.T. Effect of copper- and zinc-methionine supplementation on bioavailability, mineral status and tissue concentrations of copper and zinc in ewes. Journal of Trace Elements in Medicine and Biology, 2010, 24(2): 89-94 (doi: 10.1016/j.jtemb.2009.11.007).

26. Demirel G., Wachira A.M., Sinclair L.A., Wilkinson R.G., Wood J.D., Enser M. Effects of dietary $n-3$ polyunsaturated fatty acids, breed and dietary vitamin $\mathrm{E}$ on the fatty acids of lamb muscle, liver and adipose tissue. British Journal of Nutrition, 2004, 91(4): 551-565 (doi: 10.1079/BJN20031079).

27. Nikonova E.B., Maksimov V.I. Veterinarnaya patologiya, 2006, 3(18): 128-132 (in Russ.).

28. Ray J.G., Wyatt P.R., Thompson M.D., Vermeulen M.J., Meier C., Wong P.Y., Farrell S.A., Cole D.E. Vitamin $\mathrm{B}_{12}$ and the risk of neural tube defects in a folic-acid-fortified population. Epidemiology, 2007, 18(3): 362-366 (doi: 10.1097/01.ede.0000257063.77411.e9).

29. Fu X., Wang X.D., Mernitz H., Wallin R., Shea M.K., Booth S.L. 9-Cis retinoic acid reduces 1alpha,25-dihydroxycholecalciferol-induced renal calcification by altering vitamin K-dependent gamma-carboxylation of matrix gamma-carboxyglutamic acid protein in A/J male mice. The Journal of Nutrition, 2008, 138(12): 2337-2341 (doi: 10.3945/jn.108.093724).

30. Traber M.G., Stevens J.F. Vitamins C and E: beneficial effects from a mechanistic perspective. Free Radical Biology and Medicine, 2011, 51(5): 1000-1013 (doi: 10.1016/j.freeradbiomed.2011.05.017).

31. Van Den Berg G.J., Beynen A.C. Influence of ascorbic acid supplementation on copper metabolism in rats. British Journal of Nutrition, 1992, 68(3): 701-715 (doi: 10.1079/BJN19920127).

32. Staroverova I.N., Maksimov V.I., Zaitsev S.Yu., Egorov V.V., Kordonskaya M.A. Veterinarnaya meditsina, 2009, 3: 47-49 (in Russ.). 